\title{
PERFORMANCE OF NILE TILAPIA (Oreochromis niloticus) FINGERLINGES FED DIETS CONTAINING DIFFERENT LEVELS OF L-CARNITINE
}

\author{
A.M.A. El-Hais
}

Department of Animal Production, Faculty of Agriculture, University of Tanta, Egypt

\section{SUMMARY}

This study was designed to evaluate the effect of dietary L-carnitine supplementation at different levels (0.0, 0.25, 0.50 and $1.0 \%$ DM basis) on growth performance, feed utilization, body composition and some blood parameters of Nile tilapia, Oreochromis niloticus. Experimental diets were isonitrogenous and isocaloric (29.48\% CP and $4.55 \mathrm{kcal} / \mathrm{GE} / \mathrm{g}$ in average). A total number of 120 Nile tilapia fingerlings with an average initial body weight of $5.93 \mathrm{~g} / \mathrm{fish}$ were randomly distributed into four treatment groups and stocked into 12 glass aquaria (70 liter each). Four experimental groups in triplicate aquaria were fed daily at a rate of 5, 4 and 3\% of the body weight daily for the 1-4, 5-8 and 9-12 weeks, respectively. The results indicated that final body weight, weight gain, daily gain and specific growth rate for fish groups fed diets supplemented with L-carnitine were significantly $(P<0.05)$ higher compared with the control group. In addition, the feed conversion ratio, protein efficiency ratio in treatments receiving L-carnitine were significantly better $(P<0.05)$ than those fed the control diet. Concerning the influence of $L$ carnitine on the proximate composition of carcass, no significant differences $(P>0.05)$ were observed among different treatments in carcass moisture, crude protein, lipid, ash and energy contents. Results showed that no significant differences $(P>0.05)$ were observed among different treatments in plasma glucose, total protein and total lipids, but acted on improving each of the aspartate aminotransferase and alanine aminotransferase. In conclusion, the addition of L-carnitine in the diets, specially at level $1.0 \%$, enhances the growth performance of Nile tilapia, Oreochromis niloticus, fingerlings.

Keywords: Feed additives; L-carnitine; Nile Tilapia; growth performance and feed utilization

\section{INTRODUCTION}

Nile tilapia, Oreochromis niloticus (L.), is an important species for freshwater aquaculture. Improving fish performance and disease resistance of cultured organisms are the major challenges facing fish culturists. Moreover, bacterial diseases are one of the limiting factors for fish culture including Nile tilapia.

L-carnitine (L- $\beta$-hydroxy $\gamma$-trimethyl aminobutyrate) is a water-soluble quaternary amine that occurs naturally in microorganisms, plants and animals (Bremer, 1983) and is synthesized from the essential amino acids lysine and methionine with the assistance of vitamin $\mathrm{C}$ and other compounds produced in the body (Rebouche, 1991). It functions as a cofactor for the transport of fatty acids into

Issued by The Egyptian Society of Animal Production 
the mitochondrial matrix. Increased import of fatty acids into the mitochondria for oxidation has the potential to spare the catabolism of proteins for energy. Thus, animals fed diets with elevated L-carnitine contents may have more protein and energy available for growth.

Based on the role of carnitine in vertebrates, its supplementation in aqua feeds has been advocated for multifunctional purposes: (1) as a growth promoter; (2) providing protection against toxic levels of xenobiotics; (3) alleviating stress related to water temperature extremes; (4) inducing changes in muscle structure/texture related to higher levels of swimming activity and (5) enhancing reproduction (Harpaz 2005).

Several studies on pigs, foals and broiler chickens have shown that growth performance was significantly improved by feeding dietary L-carnitine (Weeden et al., 1991; Hausenblasz et al., 1996 and Rabie et al., 1997). Studies employing carnitine in fish have indicated growth improvement in sea bass (Santulli and D’Amelio, 1986), African catfish (Torreele et al., 1993), carp (Becker and Focken, 1995) red sea bream (Chatzifotis et al., 1995), white prawn (Jayaprakas and Sambhu, 1996) and hybrid sea bass (Twibell and Brown, 2000). On the other hand, inclusion of different levels of L-carnitine in diet has negligible or even negative effects on growth in warm water fish (Dzikowski et al., 2001 and Schlechtriem et al., 2004) and cold water fish species (Chatzifotis et al., 1997 and Gaylord and Gatlin, 2000). These differences of results between species suggest that the effects of dietary carnitine supplements are associated with different factors such as age, fish size, experimental period, feed composition and levels of supplements.

The present study aimed to determine the effect of dietary supplementation of Lcarnitine at different levels (control (0.0),0.25, 0.50 and 1\% DM basis) on growth performance, feed utilization, body composition and some blood parameters of Nile tilapia, Oreochromis niloticus, fingerlings.

\section{MATERIALS AND METHODS}

This study was carried out at the Wet Fish Laboratory, Department of Animal Production, Faculty of Agriculture, Kafr El-Sheikh University, Egypt.

\section{Experimental fish:}

Nile tilapia, Oreochromis niloticus, fingerlings were brought from a fresh water commercial farm in Motobas, Kafr El-Sheikh Governorate, Egypt. Prior to the start of the experiment, fingerlings were placed in a fiberglass tank and randomly distributed into glass aquaria to be adapted to the experimental condition until starting the experiment. Fish were fed on the control diet for two weeks, during this period healthy fish at the same weight were replaced instead of dead ones. All the experimental treatments were conduced under an artificial photo period equal to natural light/darkness period (12h light: $12 \mathrm{~h}$ darkness).

\section{Experimental Diets:}

Four experimental diets were formulated to contain L-carnitine for tilapia fingerlings. Diet one (control diet without supplements); second to fourth diets were supplemented with L-carnitine at different levels $(0.25,0.50$ and $1 \%)$, respectively. The basal and tested diets were formulated from the commercial feed ingredients. The dry ingredients were ground through a feed grinder to very small size $(0.15 \mathrm{~mm})$. 
L-carnitine was obtained from Global Napi Pharmaceuticals Company 6th, of October city.

Experimental diets were formulated (Table 1) to be isonitrogenous and isocaloric (about $29.48 \%$ crude protein and about $454.60 \mathrm{kcal} \mathrm{GE} / 100 \mathrm{~g}$ diet). The ingredients were weighed and mixed by a dough mixer for 20 minutes to homogeneity of the ingredients. The estimated amount of oil components (sunflower oil) was gradually added (few drops gradually) and the mixing operation was continued for 20 minutes. The diets were pelleted through fodder machine and the pellets were dried under room temperature. The diets were collected, and stored in plastic bags in refrigerator at $4^{\circ} \dot{\mathrm{C}}$ during the experimental period to avoid the deterioration of nutrients.

Table 1. Composition and proximate analysis of the experimental diets

\begin{tabular}{|c|c|c|c|c|}
\hline \multirow[b]{2}{*}{ Item } & \multicolumn{4}{|c|}{ Diet $^{5}$ No (on DM basis, $\%$ ) } \\
\hline & $\begin{array}{c}\text { D1 } \\
\text { Control }\end{array}$ & D2 & D3 & D4 \\
\hline \multicolumn{5}{|l|}{ Feed ingredients } \\
\hline Herring fish meal & 12 & 12 & 12 & 12 \\
\hline Soybean meal & 32 & 32 & 32 & 32 \\
\hline Yellow corn & 36 & 35.75 & 35.50 & 35.00 \\
\hline Wheat bran & 15 & 15 & 15 & 15 \\
\hline Sunflower oil & 3 & 3 & 3 & 3 \\
\hline Vitamins and minerals premix ${ }^{1}$ & 2 & 2 & 2 & 2 \\
\hline L-carnitine & 0 & 0.25 & 0.50 & 1.00 \\
\hline Total & 100 & 100 & 100 & 100 \\
\hline \multicolumn{5}{|l|}{ Chemical composition (\% DM) } \\
\hline Dry matter & 91.02 & 90.89 & 90.76 & 90.92 \\
\hline Crude protein & 29.34 & 29.46 & 29.52 & 29.58 \\
\hline Ether extract & 5.21 & 5.26 & 5.28 & 5.31 \\
\hline Crude fiber & 4.21 & 4.24 & 4.22 & 4.25 \\
\hline Total ash & 4.54 & 4.57 & 4.59 & 4.55 \\
\hline Nitrogen free extract & 56.70 & 56.47 & 56.39 & 56.31 \\
\hline \multicolumn{5}{|l|}{ Calculated energy value } \\
\hline $\mathrm{GE}(\mathrm{kcal} / \mathrm{kg})^{2}$ & 4543 & 4545 & 4547 & 4549 \\
\hline $\mathrm{DE}(\mathrm{kcal} / \mathrm{kg})^{3}$ & 3407 & 3409 & 3410 & 3412 \\
\hline $\mathrm{P} / \mathrm{E}, \mathrm{mg} / \mathrm{kcal}^{4}$ & 86.12 & 86.42 & 86.57 & 86.69 \\
\hline
\end{tabular}

${ }^{\mathrm{I}}$ Vitamins and minerals premix at $2 \%$ of the diet supplies the following per $\mathrm{kg}$ of the diet: 75000 IU Vit.A; 9000 IU Vit. D3 ; 150 mg Vit. E ; $30 \mathrm{mg}$ Vit. K3 ; $26.7 \mathrm{mg}$ Vit. B1; $30 \mathrm{mg}$ Vit. B2; $24.7 \mathrm{mg}$ Vit. B 6 ; $75 \mathrm{mg}$ Vit.B12; $225 \mathrm{mg}$ Nicotinic acid ; $69 \mathrm{mg}$ Pantothenic acid; $7.5 \mathrm{mg}$ Folic acid; $150 \mathrm{mg}$ vit. C; $150 \mathrm{mg}$ Biotien; $500 \mathrm{mg}$ Choline chlorid $300 \mathrm{mg}$ DLmethionine; $93 \mathrm{mg} \mathrm{Fe} ; 11.25 \mathrm{mg} \mathrm{Cu} ; 210 \mathrm{mg} \mathrm{Zn;} 204 \mathrm{mg} \mathrm{Mn} ; 5 \mathrm{mg}$ Se and Co $5 \mathrm{mg}$ (Local market).

${ }^{2}$ GE (Gross energy) was calculated according to NRC (1993) by using factors of 5.65, 9.45 and $4.22 \mathrm{~K}$ cal per gram of protein, lipid and carbohydrate, respectively .

${ }^{3} \mathrm{DE}$ (Digestible energy) was calculated by applying the coefficient of 0.75 to convert gross energy to digestible energy according to Hepher et al., (1983).

${ }^{4} \mathrm{P} / \mathrm{E}$ (protein energy ratio) $=$ crude protein $\mathrm{x} 10000 /$ digestible energy, according to Hepher $e t$ al. (1983).

${ }^{5}$ Treatments: T1 (control): 0\% L-carnitine, T2: 0.25\% L-carnitine, T3: 0.50\% L-carnitine and T4: $1.0 \%$ L-carnitine 


\section{Experimental design of rearing fish:}

A total of 120 Nile tilapia, Oreochromis niloticus, fingerlings with an average initial body weight of $5.93 \mathrm{~g}$ / fish were randomly divided into four treatment groups and stocked into 12 glass aquaria (70 liter each). Three aquaria were assigned for each treatment.

Fresh tap water was stored in fiberglass tanks for $24 \mathrm{~h}$ under aeration for dechlorination. One third of all aquaria were replaced daily. Five air stones were used for aerating the aquaria water. Fish feces and feed residues were removed daily by siphoning. Fish from each replicate were weighed at the start of each experiment and counted and weighted every two weeks throughout the experimental period (12 weeks).

Fish in all treatments were fed daily at a rate of 5, 4 and 3\% of the body weight daily for the 1-4, 5-8 and 9-12 weeks, respectively. The feed amount was given three times daily $(900,1200$ and 1500) in equal proportions, six days a week for 12 weeks. Fish were weighed biweekly and feed amounts were adjusted on the basis of the new weight.

\section{Chemical analysis:}

Proximate chemical analyses were made of diet ingredients and a sample of fish at the beginning and end of the experiment according to standard methods (A.O.A.C., 1992) for dry matter, crude protein, ether extract, crude fiber and ash. Gross energy (GE) contents of the experimental diets and fish samples were calculated using factors of 5.65, 9.45 and $4.22 \mathrm{kcal} / \mathrm{g}$ of protein, lipid and carbohydrates, respectively (NRC, 1993).

\section{Measurements of water parameters:}

Water samples were taken each two days for ammonia and $\mathrm{pH}$ analysis. Analytical methods were done according to the American Public Health Association (APHA, 1985). The $\mathrm{pH}$ values were determined by A digital $\mathrm{pH}$-meter. Water temperature and oxygen level were measured daily at 8 o'clock by (Oxygen meter model 9070). In all treatments water quality parameters for water temperature ranged between 27 to $28.50^{\circ} \mathrm{C}, \mathrm{pH}$ (7.3 to 8.2$)$; dissolved oxygen $(5.80$ to $6.32 \mathrm{mg} / \mathrm{L})$ and water ammonia $(0.07$ to $0.11 \mathrm{mg} / \mathrm{L})$. All the water quality parameters were within the acceptable ranges for fish growth (Boyed, 1984).

\section{Blood parameters:}

Blood samples were collected at the end of the experiment, fish in each aquarium were weighed and 5 fish were taken randomly for blood sampling. The blood was collected using heparinized syringes from the caudal vein. Blood samples were centrifuged at $4000 \mathrm{rpm}$ for 20 minutes to allow separation of plasma which was subjected to determine plasma total protein (Tietz, 1990). Blood plasma total lipids were determined according to the method of McGowan et al. (1983). Glucose concentration was determined according to Trinder (1969). Alanine aminotransferase (ALT) and activity of aspartate aminotransferase (AST) were determined by the methods of Young (1990).

\section{Statistical analysis:}

The obtained numerical data were statistically analyzed using SPSS (1997) for one-way analysis of variance. When F-test was significant, least significant difference was calculated according to Duncan (1955). 


\section{RESULTS AND DISCUSSION}

Chemical composition of the experimental diets:

Experimental diets (Table 1) contained nearly similar levels of DM, CP, EE, CF, Ash, NFE, GE, DE and $\mathrm{P} / \mathrm{E}$ ratio. The $\mathrm{CP}$ and GE content of experimental diets were around $29.48 \%$ and $4.55 \mathrm{kcal} / \mathrm{g}$, respectively. These values were within the range suggested for tilapia by Jauncey and Ross (1982) and NRC (1993).

\section{Growth performance and survival rate:}

Data in Table (2) show the growth performance and nutrient utilization efficiencies of Nile tilapia fingerlings fed diets containing L-carnitine. Statistical analysis showed no significant differences $(\mathrm{P}>0.05)$ in initial body weight among the different experimental treatments, indicating the accuracy of randomization process among the experimental treatments.

It is clearly shown in table, 2 that, the groups of fish fed diets supplemented with different levels of L-carnitine had significantly $(\mathrm{P}<0.05)$ higher growth values than the control diet (without supplements). However no significant differences were observed between fish groups fed diet supplemented with L-carnitine.

Results showed that, treatments $\mathrm{T}_{3}$ to $\mathrm{T}_{4}$ had statistically higher feed conversion ratios compared with the control diet $(\mathrm{P}<0.05)$. The best conversion ratio $(1.31 \mathrm{~g}$ feed/g gain) was recorded for T2 (1\% supplementation of L-carnitine).

Table 2. Growth performance parameters of Nile tilapia (O. niloticus) fed on the experimental diets

\begin{tabular}{|c|c|c|c|c|c|}
\hline \multirow[t]{2}{*}{ Items } & \multicolumn{4}{|c|}{ Treatments } & \multirow[t]{2}{*}{$\pm \mathrm{SE}^{*}$} \\
\hline & $\mathrm{T}_{1}$, Control & $\mathrm{T}_{2}$ & $\mathrm{~T}_{3}$ & $\mathrm{~T}_{4}$ & \\
\hline Initial weight, $\mathrm{g}$ /fish & 5.90 & 5.93 & 5.92 & 5.95 & 0.06 \\
\hline Final weight, $\mathrm{g} /$ fish & $30.00^{\mathrm{b}}$ & $31.07^{\mathrm{b}}$ & $36.14^{\mathrm{a}}$ & $37.60^{\mathrm{a}}$ & 0.68 \\
\hline Average total gain ${ }^{1}, \mathrm{~g} /$ fish & $24.10^{\mathrm{b}}$ & $25.14^{\mathrm{b}}$ & $30.22^{\mathrm{a}}$ & $31.65^{\mathrm{a}}$ & 1.23 \\
\hline Average daily gain ${ }^{2}, \mathrm{~g} / \mathrm{fish} /$ day & $0.29^{\mathrm{b}}$ & $0.30^{\mathrm{b}}$ & $0.36^{\mathrm{a}}$ & $0.38^{\mathrm{a}}$ & 0.02 \\
\hline $\begin{array}{l}\text { Specific growth rate }{ }^{3} \text { (SGR \% } \\
\text { /day) }\end{array}$ & $1.94^{\mathrm{b}}$ & $1.97^{\mathrm{b}}$ & $2.15^{\mathrm{a}}$ & $2.19^{\mathrm{a}}$ & 0.09 \\
\hline Survival rate ${ }^{4}, \%$ & 90 & 90 & 95 & 100 & 0.001 \\
\hline Feed intake $(\mathrm{FI}), \mathrm{g} /$ fish & 39.62 & 40.20 & 40.41 & 41.42 & 1.97 \\
\hline Feed conversion ratio ${ }^{5}(\mathrm{FCR})$ & $1.64^{\mathrm{a}}$ & $1.60^{\mathrm{a}}$ & $1.34^{\mathrm{b}}$ & $1.31^{\mathrm{b}}$ & 0.13 \\
\hline Protein efficiency ratio $^{6}$ (PER) & $2.07^{\mathrm{b}}$ & $2.12^{\mathrm{b}}$ & $2.53^{\mathrm{a}}$ & $2.58^{\mathrm{a}}$ & 0.19 \\
\hline $\begin{array}{l}\text { Protein productive value } \\
(\mathrm{PPV}, \%)\end{array}$ & $31.83^{\mathrm{b}}$ & $33.04^{b}$ & $39.23^{\mathrm{a}}$ & $41.21^{\mathrm{a}}$ & 2.14 \\
\hline Energy retention $^{8}(\mathrm{ER}, \%)$ & $20.10^{\mathrm{b}}$ & $20.84^{\mathrm{b}}$ & $24.56^{\mathrm{a}}$ & $25.01^{\mathrm{a}}$ & 0.87 \\
\hline $\begin{array}{l}\text { *Means in the same rows having differe } \\
\text { * Standard error of the mean derived fro } \\
\text { 1. ATG }(\mathrm{g} / \text { /ish })=\text { Average final weight } \\
\text { 2. ADG }(\mathrm{g} / \text { fish/day })=[\text { ATG }(\mathrm{g}) / \text { experi } \\
\text { 3. SGR }(\% / \text { day })=100(\text { Ln final weight- } \\
\text { 4. SR }=100[\text { Total No of fish at the end } \\
\text { 5. FCR }=\text { DM Feed Intake }(\mathrm{g}) / \text { Live wei } \\
\text { 6. PER }=\text { Live weight gain }(\mathrm{g}) / \text { Protein } \\
\text { 7. PPV }(\%)=100[\text { Final fish body prote } \\
\text { 8. ER } \%=100 \text { [gross energy gain / gros }\end{array}$ & $\begin{array}{l}\text { erscript letters } \\
\text { analysis of var } \\
\text { iverage initial v } \\
\text { period (d)]. } \\
\text { tial weight)/exp } \\
\text { experimental/Tc } \\
\text { n (g). } \\
\text { (g). }\end{array}$ & $\begin{array}{l}\text { rimental pe } \\
\text { al No of fis }\end{array}$ & $\begin{array}{l}\text { od (d). } \\
\text { at the star }\end{array}$ & of the expe & iment]. \\
\hline
\end{tabular}


In general, fish fed diets supplemented with L-carnitine showed better feeding efficiency than those fed with control diet (without supplement). The protein efficiency ratio (PER), protein productive value (PPV \%) and energy retention (ER $\%)$ were significantly higher in the groups fed diets containing L-carnitine than the control one (Table, 2). The lowest PER, PPV and ER values were recorded for the control treatment.

The results obtained from this study clearly point out that L-carnitine has a positive effect on growth rates and feed utilization of Nile tilapia fingerlings. Fish receiving L-carnitine level of $1 \%\left(\mathrm{~T}_{4}\right)$ in their diet showed the highest increase in growth rate and feed utilization. Similar studies on other tilapia species including Mozambique tilapia (Oreochromis mossambicus) (Jayaprakas et al., 1996), hybrid tilapia Oreochromis niloticus $\times$ O. aureus (Becker et al., 1999) and Nile tilapia (Abou-Seif, 2006 and Abdel-Fattah et al., 2010) revealed that dietary L-carnitine supplementation resulted in improved growth rates and feed efficiency. Similar results have also been reported with several other species reared on diets supplemented with L-carnitine, including European sea bass (Santulli and D'Amelio, 1986), African catfish (Clarias gariepinus) (Torreele et al., 1993; Ozorio et al., 2001), red sea bream (Chatzifotis et al., 1995), Indian major carp rohu (Keshavanath and Renuka, 1998); hybrid striped bass (Twibell and Brown, 2000).

In the current study, dietary L-carnitine may have indirectly increased carnitine synthesis and consequently promoted lipolysis activity. Thus, promoted lipolysis activity may have an effect on protein accumulation in tested fish. However, it was important for the objectives of the present trail to note that there was an obvious effect of L-carnitine on the growth and fatty acid composition. Several enzymes are involved in the lipid and carnitine metabolism process. For instance, carnitine palmitolytransferase, as lipolysis enzyme, performs a function to exchange of coenzyme A for carnitine to facilitate the transfer of acyl groups into mitochondria for $\beta$-oxidation (Ji et al., 2009).

A significantly higher feed conversion appeared in control group for fish fed with control diet (1.64) compared with $\mathrm{T}_{2}$ (1.60); $\mathrm{T}_{3}(1.34)$ and $\mathrm{T}_{4}$ (1.31). Supplementation with $1 \%$ L-carnitine saves $0.33 \mathrm{~kg}$ feed per $\mathrm{kg}$ body weight gain, which is $20 \%$ less than the feed required for the control group. This aspect is of practical importance for the fish culturist both from an ecological and economic point of view. The significant differences of FCR in the experiment, may suggest that the improved growth was related to feed consumption and better feed utilization efficiency. Therefore, the improved performance of Nile tilapia in the experiment with $1 \%$ L-carnitine supplementation is presumably due to the enhancement, caused by carnitine, of energy utilization from fatty acid oxidation (Torreele et al., 1993 and Chatzifotis et al., 1995). It has also been reported that L-carnitine facilitates the removal of short chain organic acids from the mitochondria, leading to freeing coenzyme A to participate in â-oxidation and tricarboxylic acid cycle pathways (Harpaz, 2005).

These findings have also been supported by Becker et al. (1999), who observed that low level supplementation of L-carnitine $(150 \mathrm{mg} \mathrm{kg}-1)$ for tilapia is effective but not the best supplementation level (300 mg kg-1). Supplemental dietary Lcarnitine showed positive effects in terms of growth rate and food conversion ratio of red sea bream (Chatzifotis et al., 1995; 1996), tilapia (Jayaprakas et al., 1996; Dikel et al., 2003), European sea bass (Santulli and D'Amelio, 1986) and African catfish (Torreele et al., 1993), hybrid striped bass (Twibell and Brown, 2000). In contrast 
dietary carnitine did not affect weight gain of the channel catfish (Burtle and Liu, 1994), rainbow trout (Rodehutscord, 1995) or Atlantic salmon (Ji et al., 1996). However, in the present study, growth rate and FCR of Nile tilapia fingerlings have been positively affected by L-carnitine administration. It is difficult to explain these conflicts because the mechanisms by which supplemental dietary L-carnitine may exert such beneficial effects in terms of growth performance are still little understood in fish. For these reasons, L-carnitine supplementations in fish have shown conflicting results even with the same species, like hybrid stripped bass which reported by Twibell and Brown (2000) and Gaylord and Gatlin (2000).

In contrast, no effects of L-carnitine supplementation was reported in European sea bass (Dias et al., 2001), Channel catfish (Burtle and Liu, 1994), Atlantic salmon (Ji et al., 1996), Rainbow trout (Chatzifotis et al., 1997), hybrid striped bass (Gaylord and Gatlin 2000 a,b), African catfish (Ozorio et al., 2001 a and b) and hybrid tilapia O. niloticus $\times$ O. aureus (Schlechtriem et al., 2004). The discrepancies in these results may have been due to the differences in culture conditions, diets composition and fish species and sizes.

\section{Body composition:}

The influence of different dietary L-carnitine levels on chemical composition of fish carcass is shown in Table (3). No significant differences $(\mathrm{P}<0.05)$ were observed in dry matter, crude protein, ether extract, ash and energy contents. Also, fish at the start of the experiment had lower dry matter, crude protein, ether extract, ash and energy contents than at the end of the experiment. This result was in agreement with Saad et al. (2009).

These results suggest that L-carnitine supplementation plays a role in enhancing feed intake with a subsequent enhancement of fish body composition. The better feed intake in feed additives supplemented diets may have been due to increased fish appetite resulting in a higher feed intake and therefore improved growth. Moreover, due to the high feed intake and nutrient utilization, the deposited nutrients increased.

Table 3. Effect of L-carnitine on Nile tilapia body composition (\%, on DM basis)

\begin{tabular}{|c|c|c|c|c|c|c|}
\hline \multirow{2}{*}{ Items } & \multirow{2}{*}{$\begin{array}{l}\text { Initial } \\
\text { fish }\end{array}$} & \multicolumn{4}{|c|}{ Treatments } & \multirow[t]{2}{*}{$\pm \mathrm{SE}^{*}$} \\
\hline & & $\mathrm{T}_{1}$ & $\mathrm{~T}_{2}$ & $\mathrm{~T}_{3}$ & $\mathrm{~T}_{4}$ & \\
\hline Dry matter, $\%$ & 21.42 & 26.33 & 26.54 & 26.26 & 26.17 & 0.27 \\
\hline Crude protein, $\%$ & 54.10 & 55.44 & 55.81 & 56.58 & 58.32 & 2.42 \\
\hline Ether extract, \% & 16.35 & 18.24 & 18.42 & 18.80 & 18.01 & 1.34 \\
\hline Ash, $\%$ & 11.47 & 12.47 & 12.73 & 12.80 & 12.25 & 1.22 \\
\hline Energy, Kcal/100g & 537 & 544 & 544 & 547 & 548 & 3.87 \\
\hline
\end{tabular}

*Means in the same rows having different superscript letters were significantly different at 0.05 level.

${ }^{*}$ Means of the standard error derived from the analysis of variance.

\section{Biochemical blood parameters:}

Results in Table (4) showed that, blood plasma glucose, total protein and total lipids, were not significantly affected $(\mathrm{P}<0.05)$ by the different levels of L-carnitine. A slight decrease in plasma glucose and slight decrease in plasma total lipid were observed. These results suggested that fish health was improved when fed diets 
supplemented with. Moreover, feed additives supplementation significantly $(\mathrm{P}<0.05)$ decreased aspartate aminotransferase (AST) and alanine aminotransferase (ALT) values compared with control group (without supplementation). Biochemical analyses often provide vital information for health assessment and management of cultured fish (Cnaani et al., 2004).

Table 4. Blood plasma parameters of Nile tilapia fed on the experimental diets

\begin{tabular}{|c|c|c|c|c|c|}
\hline \multirow[b]{2}{*}{ Items } & \multicolumn{4}{|c|}{ Treatments } & \multirow[b]{2}{*}{$\pm \mathrm{SE}^{*}$} \\
\hline & $\begin{array}{c}\mathrm{T}_{1}, \\
\text { Control }\end{array}$ & $\mathrm{T}_{2}$ & $\mathrm{~T}_{3}$ & $\mathrm{~T}_{4}$ & \\
\hline Plasma glucose, mg/dl & 57.75 & 57.54 & 56.78 & 56.54 & 0.40 \\
\hline Plasma total protein, $\mathrm{g} / \mathrm{dl}$ & 5.24 & 5.64 & 5.75 & 5.81 & 0.10 \\
\hline Plasma total lipid, g/dl & 4.21 & 4.11 & 4.15 & 4.18 & 0.02 \\
\hline AST, U/dl & $125^{\mathrm{a}}$ & $118^{\mathrm{b}}$ & $110^{\mathrm{b}}$ & $111^{\mathrm{b}}$ & 2.98 \\
\hline $\mathrm{ALT}, \mathrm{U} / \mathrm{dl}$ & $55^{\mathrm{a}}$ & $43^{\mathrm{b}}$ & $42^{\mathrm{b}}$ & $40^{\mathrm{b}}$ & 1.21 \\
\hline
\end{tabular}

*Means in the same rows having different superscript letters were significantly different at 0.05 level.

* Standard error of the mean derived from the analysis of variance.

This result agrees with Abdel-Tawwab et al. (2008) who investigated the use of commercial probiotic as a growth and immunity promoter for Nile tilapia, Oreochromis niloticus, since they found that biochemical parameters were improved in fish fed probiotic.

\section{CONCLUSION}

It can be concluded that the addition of L-carnitine in tilapia fingerlings diets improves fish growth and feed utilization .Based on these results, use of a $1 \% \mathrm{~L}$ carnitine in tilapia fingerlings feeds is recommended to stimulate growth performance.

\section{REFERENCES}

Abdel-Fattah M.E., N.F. Abdel-Hakim, Hanan A. Abo-State, K.F.E. and A.A. Dosoky, 2010. Effects of L-carnitine on growth performance of Nile tilapia (Oreochromis niloticus) fingerlings fed basal diet or diets containing decreasing protein levels. Journal of American Science, 6 (5): 165-172.

Abdel-Tawwab M.; Azza M. Abdel-Rahman and Nahla E.M. Ismael, 2008. Evaluation of commercial live bakers' yeast, Saccharomyces cerevisiae as a growth and immunity promoter for Fry Nile tilapia, Oreochromis niloticus (L.) challenged in situ with Aeromonas hydrophila. Aquaculture, 280: 185-189.

Abou-Seif R.A., 2006. Effects of Biogenic Lcarnitine supplementation on growth performance, survival rate and feed efficiency of monosex Nile Tilapia (Oreochromis niloticus L.) fry during the nursery period. Egyptian Journal of Nutrition and feeds, 9:71-82.

APHA (American Public Health Association), 1985. Standard methods for the examination of water and waste. 12th addition, Inc. New York. Pp. 769. 
A.O.A.C., 1992. Official Methods of Analysis of the Association of Official Analytical Chemists, 14th ed. AOAC, Arlington, 3413 pp.

Becker K. and U. Focken, 1995. Effect of feed supplementation with L-carnitine on growth, metabolism and body composition of carp (Cyprinus capio L.). Aquaculture, 129: 34-43.

Becker K.; S. Schreiber; C. Angoni and R. Blum, 1999. Growth performance and feed utilization response of Oreochromis niloticus $\times$ Oreochromis aureus hybrids to L-carnitine measured over a full fattening cycle under commercial conditions. Aquaculture, 174; 313-322.

Boyd C.E., 1984. Water Quality in Warm water Fishponds. Auburn University Agriculture Experimental Station, Auburn, AL, USA (Oncorhynchus tshawytscha) and rainbow trout (Oncorhynchus mykiss). Aquaculture 161, 2743.

Bremer J., 1983. Carnitine metabolism and functions. Physiology Rev., 63: 14201480.

Burtle G.J. and Q. Liu, 1994. Dietary carnitine and lysine affect channel catfish lipid and protein composition. Journal of World Aquaculture Society. 25, 169-174.

Chatzifotis S.; T. Takeuchi and T. Seikai, 1995. The effect of dietary 1-carnitine on growth performance and lipid composition in red sea bream fingerlings. Fish. Sci., 61: 1004-1008.

Chatzifotis S.; T. Takeuchi and T. Seikai, 1996. The effect of dietary supplementation 1-carnitine on growth of red sea bream Pagrus major fingerlings at two levels of dietary lysine. Aquaculture, 147: 235-248.

Chatzifotis S.; T. Takeuchi; T. Watanabe and S. Sato, 1997. The effect of dietary carnitine on growth rainbow trout fingerlings. Fish. Sci., 63(2): 321-322.

Cnaani A.; S. Tinman; Y. Avidar; M. Ron and G. Hulata, 2004. Comparative study of biochemical parameters in response to stress in Oreochromis aureus, $O$. mossambicus and two strains of $O$. niloticus. Aquaculture Research. 35, 14341440.

Dias J., J. Arzel, G. Corraze and S. J. Kaushik, 2001. Effect of dietary L-carnitine supplementation on growth and lipid metabolism in European seabass (Dicentrarchus labrax). Aquaculture Research, 32 : 206-215.

Dikel S.; M. V. Alev; G. A. Kiris and M. Celik, 2003. Effects of supplemental dietary L-carnitine on the growth of Nile tilapia (Oreochromis niloticus) in cage conditions. Turk. J. Vet. Anim. Sci., 27: 663-669.

Duncan M.B., 1955. Multiple ranges and multiple F-tests. Biometrics, 11:1-42.

Dzikowski R.; G. Hulata; I. Karplus and S. Harpaz, 2001. Effect of temperature and dietary L-carnitine supplementation on reproductive performance of female guppy (Poecilia reticulate). Aquaculture, 199: 323-332.

Gaylord T.G. and M.D. Gatlin, 2000. Effects of dietary carnitine and lipid on growth and body composition of hybrid striped bass (Morone chrysops female $\mathrm{x}$ Msaxatilis male). Fish Physiology and Biochemistry, 2: 297-302.

Harpaz S., 2005. L-Carnitine and its attributed functions in fish culture and nutritiona review. Aquaculture, 249: 3-21.

Hausenblasz J., M. Acs, A. Petri and M. Mezes, 1996. Effect of L-carnitine on some metabolic parameters of foals. Allattenyesztes es takarmanyozas, 45: 397-403. 
Hepher B., I. C. Liao, S. H. Cheng and C. S. Haseih, 1983. Food utilization by red tilapia. Effect of diet composition, feeding level and temperature on utilization efficiency for maintenance and growth. Aquaculture, 32: 255 - 272.

Jauncey K. and B. Ross, 1982. A guide to tilapia feeds and feeding Ins. Aquaculture, Univ. Sterling, FK94 La, Scotland, U.K.111 pp.

Jayaprakas V. and C. Sambhu, 1996. Growth response of white prawn, Penaeus indicus, to dietary L-carnitine. Asian Fisheries Science, 9: 209-219.

Jayaprakas V.; C. Sambhu and S. Sunil Kumar, 1996. Effect of dietary L-carnitine on growth and reproductive performance of male Oreochromis mossambicus (Peters). Fisheries. Technology, $33: 84-90$.

Ji H.; T. M. Bradley and G. C. Tremblay, 1996. Atlantic salmon Salmo salar fed Lcarnitine exhibit altered intermediary metabolism and reduced tissue lipid, but no change in growth rate. J. Nutr., 126: 1937-1950.

Ji H.; A. D. Om; T. Yoshimatsu; T. Umino; H. Nakagawa and S. Sakamato, 2009. Effect of dietary ascorbate on lipogenesis and lipolysis activities in black sea bream, Acanthopagrus schlegelii. Fish Physiol. Biochem., DOI 10.1007/s 10695009-9349-z.

Keshavanath P. and P. Renuka, 1998. Effect of dietary L-carnitine on growth and body composition of fingerling rohu, Labeo rohita (Hamilton). Aquaculture Nutrition, 4 : 83-87.

McGowan M. W.; J. D. Artiss; D. R. Standbergh and B. A. Zak, 1983. Peroxidasecoupled method for colorimetric determination of serum triglycerides. Clin. Chern., 29: 538.

NRC, 1993. Nutrition requirements of fish. National Research Council National academy press, Washington, D. C. 114 pp, USA.

Ozorio R.O.A.; T. H. B. Van Eekeren; E. A. Huisman and J. A. J. Verreth, 2001. Effects of dietary carnitine and protein energy: non protein energy ratios on growth, ammonia excretion and respiratory quotient in African Catfish, Clarias gariepinus (Burchell) Juveniles. Aquaculture. Res., 32: 406-414.

Rabie M.H.; M. Szilagyi and T. Gippert, 1997. Effects of dietary L-carnitine supplementation and protein level on performance and degree of meatiness and fatness of broilers. Acta Biologica Hungarica, 48: 221-239.

Rebouche C.J., 1991. Ascorbic acid and carnitine biosynthesis. Amer. J. Clin. Nutrition. 54: 1147-1152.

Rodehutscord M., 1995. Effects of supplemental dietary Lcarnitine on growth and body composition of rainbow trout Oncorhynchus mykiss Fed High-Fat Diets. J.Anim. Nutr., 73: 276-279.

Saad S. Amal; Habashy, M. Madlen and Sharshar M. Khadiga, 2009. Growth Response of the Freshwater Prawn, Macrobrachium rosenbergii (De Man), to Diets Having Different Levels of Biogen. World Applied Sciences Journal 6 : 550-556.

Santulli A. and V. D'Amelio, 1986. Effects of Supplemental Dietary Carnitine on Growth and Lipid Metabolism of Hatchery-Reared Sea Bass Dicentrarchus labrax L. Aquaculture, 59: 177-186.

Schlechtriem C.; V. Bresler; L. Fishelson; M. Rosenfeld and K. Becker, 2004. Protective effects of dietary Lcarnitine on tilapia hybrids (Oreochromis niloticus $\mathrm{x}$ Oreochromis aureus) reared under intensive pondculture conditions. Aquaculture Nutrition, 10: 55-63. 
SPSS, 1997. Statistical package for the social sciences, Versions 6, SPSS in Ch, ChiUSA.

Tietz N. W., 1990. Clinical Guide to Laboratory Tests 2nd Ed. Philadelphia.

Torreele E.; A. Van Der Sluizen and J. Verreth, 1993. The Effect of Dietary Lcarnitine on the Growth Performance in Fingerlings of the African Catfish Clarias gariepinus in Relation to Dietary lipid. Br. J. Nutr., 69: 289-299.

Trinder B., 1969. Ann. Clin. Biochem. 6: 24-32.

Twibell R.G. and P.B. Brown, 2000. Effects of Dietary Carnitine on Growth Rates and Body Composition of Hybrid Striped Bass (Morone saxatilis male $\times \mathrm{M}$. chrysops female). Aquaculture, 187: 153-161.

Weeden T.L.; J. L. Nelssen; J. A. Hansen; G. E. Fitzner and R. D. Goodband, 1991. The effect of L-carnitine on starter pig performance and carcass composition. Journal of Animal Science, 69: 105 Abstract.

Young D. S., 1990. Effects of drugs on clinical laboratory tests. 3rd Ed. 3: 6. 
إستجابة النمو لإصبعيات البلطي النيلي للتغذيه على علائق محتوية على نسب مختلفة من الكارنيتين

عبد العزيز محمد عبد العزيز الحايس

قسم الإتتاج الحيوانسي ، كلية النزراعة، جامعة طنطا

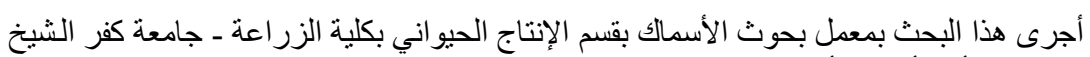

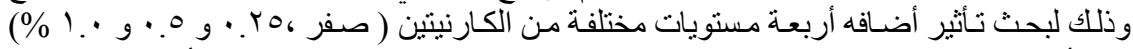

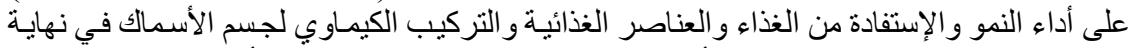

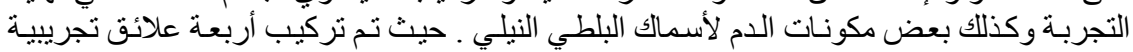

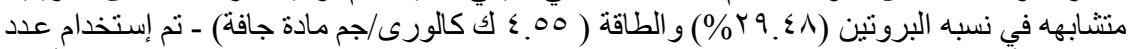

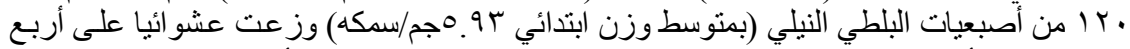

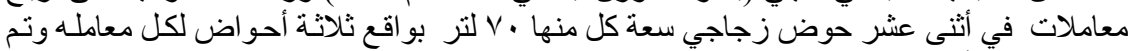

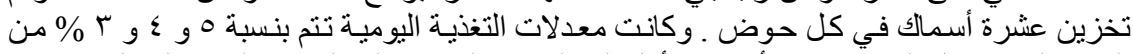

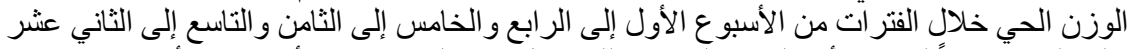

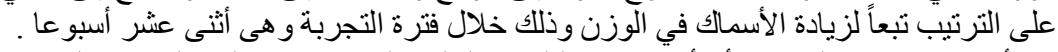

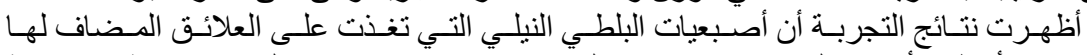

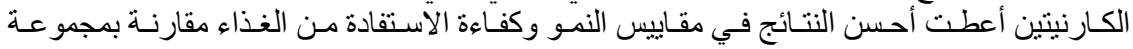

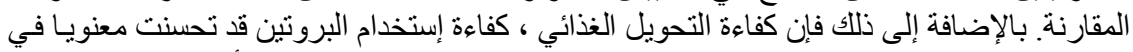

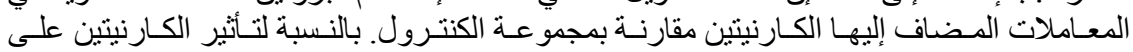

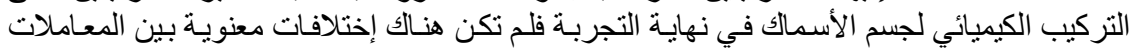

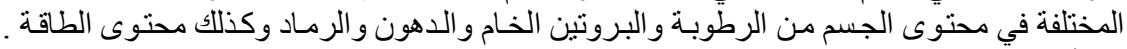

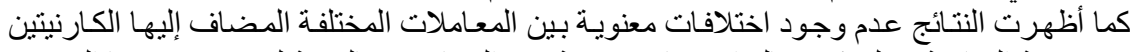

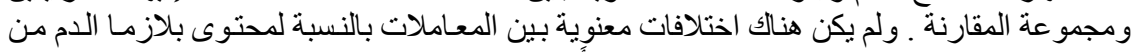

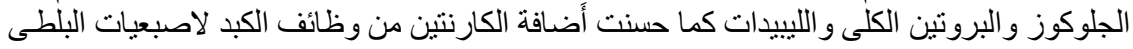

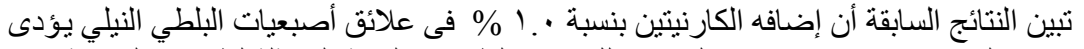

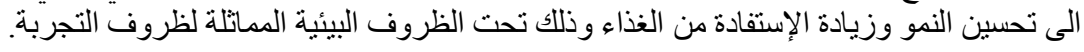

